\title{
Short communication: Rumination and feeding behavior before and after calving in dairy cows
}

\author{
K. Schirmann, N. Chapinal, D. M. Weary, L. Vickers, and M. A. G. von Keyserlingk ${ }^{1}$ \\ Animal Welfare Program, Faculty of Land and Food Systems, The University of British Columbia, 2357 Main Mall, Vancouver, BC, \\ V6T 1 Z4 Canada
}

\begin{abstract}
The objectives of the current study were to describe changes in rumination and feeding behavior around calving. Rumination time, feeding time, and dry matter intake were monitored in 11 freestall-housed cows from $96 \mathrm{~h}$ before to $48 \mathrm{~h}$ after calving. Data were summarized in 2-h and 24-h periods, adjusting for calving time. Differences between baseline (96 to $24 \mathrm{~h}$ before calving) and subsequent 24 -h periods were evaluated. Compared with baseline, cows spent, on average, $63 \pm$ $30 \mathrm{~min} / 24 \mathrm{~h}$ less time ruminating and $66 \pm 16 \mathrm{~min} / 24$ $\mathrm{h}$ less time feeding in the 24 -h period before calving. These behaviors continued to decline during the 24-h period after calving when, compared with baseline, time spent ruminating decreased on average by $133 \pm$ $35 \mathrm{~min} / 24 \mathrm{~h}$ and time spent feeding decreased by 82 $\pm 18 \mathrm{~min} / 24 \mathrm{~h}$. Dry matter intake tended to decrease by $3.8 \pm 1.9 \mathrm{~kg}$ in the 24 -h period before calving but returned to baseline values in the 24-h following calving. Rumination time and time spent feeding started to decline approximately 4 and $8 \mathrm{~h}$ before calving, respectively, and increased in the 4 to $6 \mathrm{~h}$ following calving. Rumination time and time spent feeding show promise as tools to identify cows close to calving.
\end{abstract}

Key words: welfare, Holstein, parturition, dry matter intake

\section{Short Communication}

Providing a comfortable environment around parturition is important to minimize the risk of dystocia and enhance the subsequent health of the cow and the calf (Mee, 2004), but identifying cows that are about to calve can be difficult on farm. The onset of calving is typically determined by visual signs, such as udder firmness, pelvic ligament relaxation, and vulval swelling (Berglund et al., 1987), but there is a large variability in these signs. For example, the relaxation of the sacro-

Received May 14, 2013.

Accepted July 28, 2013

${ }^{1}$ Corresponding author: nina@mail.ubc.ca sciatic ligaments has been reported to start, on average, 1 wk before calving but can range from as early as 15 $\mathrm{d}$ to only $7 \mathrm{~h}$ before the calf is born (Berglund et al., 1987). Other signs, such as vulva edematization and milk leakage from the teats, are more consistent across animals but are also recognized as being associated with the first stage of labor (Wehrend et al., 2006) or even the second stage in the case of amniotic sac appearance (Noakes et al., 2001). Moving a cow during the first stage of labor may interrupt and prolong parturition (Wehrend et al., 2006; Mainau and Manteca, 2011). Proudfoot et al. (2013) showed that moving cows in the advanced first stage of labor prolonged the second stage. Similarly, Carrier et al. (2006) reported a 2.5-fold increase in stillbirths for cows that were moved late in the first stage of labor.

Recent studies have identified changes in behaviors associated with calving that can be monitored automatically on farm. Miedema et al. (2011) visually assessed feeding time during the $24 \mathrm{~h}$ before calving and compared it with baseline recordings during the late prepartum period and found a decrease in feeding time during the $6 \mathrm{~h}$ before calving. Methods exist to automatically monitor individual feeding behavior and DMI in group-housed cows (Chapinal et al., 2007), but these systems can be expensive and technically challenging for routine use on commercial farms. More recent work has shown that the automatic monitoring of rumination time can be practical for use on commercial farms (Schirmann et al., 2009).

Normal rumination behavior has been considered an indicator of well-being in cattle (Radostits et al., 2007), and rumination is the second most common behavior (after grazing) expressed by pastured cattle (Kilgour, 2012). Rumination can be monitored using rumination loggers attached to collars (Schirmann et al., 2009).

Two recent studies (Adin et al., 2009; Soriani et al., 2012) found decreases in rumination time on the day of calving, but neither reported changes relative to calving time, making it difficult to assess to what extent this decrease happened before the calf was expelled. The objectives of the current study were to determine changes in rumination and feeding behavior around 
calving. We hypothesized that both behaviors would decrease as expulsion of the calf approached.

Eleven multiparous Holstein dairy cows (mean parity $\pm \mathrm{SD}=3.9 \pm 1.9 ;$ range $=2$ to 8 ) at The University of British Columbia's Dairy Education and Research Centre (Agassiz, BC, Canada) were used in the current study. All animals were managed and cared for according to the guidelines set by the Canadian Council on Animal Care (2009). Prepartum cows were housed in a group pen containing 24 freestalls and moved to a fresh cow pen containing 12 freestalls after calving. All freestalls were fitted with a mattress (Pasture Mat, Promat Inc., Woodstock, ON, Canada) covered with approximately $5 \mathrm{~cm}$ of sand bedding. Cows had access to 12 Insentec feed bins (Insentec BV, Marknesse, the Netherlands) and 2 Insentec water troughs during the prepartum period and 6 Insentec feed bins and 1 Insentec water trough during the postpartum period. In both groups (pre- and postpartum), the cow:stall ratio was 1:1 and stocking density was constant. Group composition was dynamic, with cows entering and leaving the group pen depending on their expected and actual calving dates. When a cow was removed from either the prepartum or the postpartum pen, another cow was immediately moved to that pen to maintain a constant stocking density; if necessary, cows from the main herd, at a similar stage of lactation, were used as filler cows.

Prepartum cows were checked multiple times a day for relaxation of tail ligaments, vulval discharge, and milk letdown, and were moved to a sawdust-bedded maternity pen (equipped with 1 Insentec feed bin and a self-filling water trough) when calving was considered imminent. However, 4 cows were not identified as calving approached and calved in the prepartum pen; these animals were moved after calving. The other cows were moved to the maternity pen within $1 \mathrm{~h}(\mathrm{n}=4), 2 \mathrm{~h}$ $(\mathrm{n}=1), 3 \mathrm{~h}(\mathrm{n}=1)$, or $4 \mathrm{~h}(\mathrm{n}=1)$ before calving. Cow and calf were separated within $2.6 \pm 1.3 \mathrm{~h}$ after calving and the calves were moved to a separate calf barn. Cows were milked at the next scheduled milking (morning or afternoon) and moved to the postpartum pen immediately after milking.

Pre- and postpartum groups were fed a TMR twice daily at approximately 0700 and $1600 \mathrm{~h}$. The TMR was formulated according to the recommendations provided by NRC (2001). Prepartum cows were fed a close-up ration from 3 wk prepartum until calving. After calving, cows were fed the regular lactating diet following standard farm procedure. Total mixed ration samples were taken twice weekly at the time of fresh feed delivery, and samples were pooled weekly. The samples were stored in a freezer and then thawed and dried at $60^{\circ} \mathrm{C}$ for $48 \mathrm{~h}$ to determine DM content. Samples were then pooled monthly and sent to Cumberland Valley Ana- lytical Services Inc. (Maugansville, MD; Cumberland Valley Analytical Services, 2013) and analyzed using wet chemistry methods, according to the standards of AOAC International (2005), to determine average $( \pm \mathrm{SD}) \mathrm{CP}, \mathrm{ADF}, \mathrm{NDF}$, and $\mathrm{NE}_{\mathrm{L}}$ content of the diets fed throughout the study. The prepartum TMR consisted of $44.0 \%$ alfalfa hay, $33.0 \%$ corn silage, and $23.0 \%$ mineral and concentrate mix on a DM basis (CP: 15.0 \pm 0.6 ; ADF: $29.4 \pm 1.9 ; \mathrm{NDF}: 29.4 \pm 1.9$; and $\mathrm{NE}_{\mathrm{L}}$ : $1.45 \pm 0.02 \mathrm{Mcal} / \mathrm{kg})$. The postpartum TMR consisted of $5.0 \%$ alfalfa hay, $29.0 \%$ corn silage, $11.0 \%$ grass silage, $4.0 \%$ grass hay, and $51 \%$ mineral and concentrate mix on a DM basis (CP: $16.9 \pm 0.7$; ADF: $21.5 \pm 1.2$; $\mathrm{NDF}: 35.6 \pm 1.9$; and $\left.\mathrm{NE}_{\mathrm{L}}: 1.59 \pm 0.1 \mathrm{Mcal} / \mathrm{kg}\right)$. For a more detailed description of the diet, see Vickers et al. (2012).

Previously frozen TMR samples were thawed and analyzed using the Penn State Particle Separator (Kononoff et al., 2003) consisting of 3 sieves and the bottom pan. The pore sizes of the 3 sieves were $19 \mathrm{~mm}$ (upper sieve), $8 \mathrm{~mm}$ (middle sieve), and $1.18 \mathrm{~mm}$ (lower sieve). The prepartum TMR was composed of $24.4 \%$ of particles $>19 \mathrm{~mm}, 39.2 \%$ of particles $>8 \mathrm{~mm}, 24.6 \%$ of particles $>1.18 \mathrm{~mm}$, and $11.8 \%$ of particles $<1.18 \mathrm{~mm}$. The postpartum TMR was composed of $22.5 \%$ particles $>19 \mathrm{~mm}, 35.0 \%$ of particles $>8 \mathrm{~mm}, 29.8 \%$ of particles $>1.18 \mathrm{~mm}$, and $12.7 \%$ of particles $<1.18 \mathrm{~mm}$. Particle lengths are reported for descriptive purposes only.

To monitor rumination time, all cows were fitted with an individual rumination logger (HR-Tag, SCR Engineers Ltd., Netanya, Israel) fitted to the collar. This logger has a built-in microphone that allows for the recording of the sound of rumination. Time spent ruminating was recorded using a 2-min resolution and stored in 2-h intervals, as described and validated by Schirmann et al. (2009). For automatic data transfer, identification units using infrared technology were placed above the water bins. These units captured the data that were then sent to a computer.

The Insentec system, previously validated by Chapinal et al. (2007), was used to record individual feed intake and time spent feeding. The cow's individual radio frequency identification transponder opened the feed bin and allowed the Insentec system to record the time the cow entered the bin as well as the duration of her visit at the feed bin and the amount of feed consumed during that visit. Recorded feed intake and the measured DM content were used to calculate DMI. The duration and intake of each visit to the feed bin were summed to calculate total feeding time and DMI by 2 -h intervals.

Continuous video was recorded using cameras (WVBP330, Panasonic, Osaka, Japan) $6 \mathrm{~m}$ above the pen. Cameras were connected to a digital video recording 


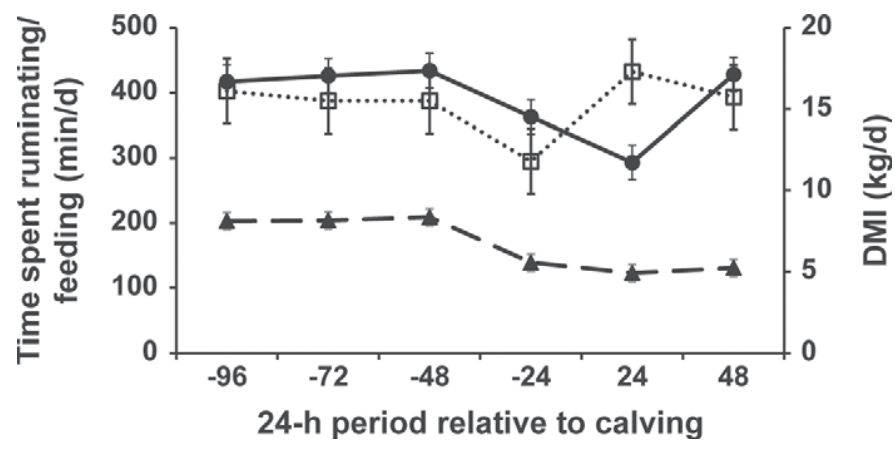

Figure 1. Least squares means $( \pm \mathrm{SE})$ for daily time spent rumi-

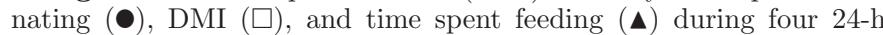
periods before and two 24 -h periods after calving ( $\mathrm{n}=11$ cows).

system (Genetec Inc., Saint-Laurent, QC, Canada). The exact time of calving (defined as the time at which the calf was fully expelled) was obtained from video recordings.

All behaviors (time spent ruminating, DMI, and time spent feeding) were summarized in 2 -h intervals (time of the interval refers to the start of the $2 \mathrm{~h}$ ). We summarized these intervals within each 24 -h period to obtain 1 value per cow and day. The 2-h intervals and 24-h periods were adjusted for actual calving time; thus the period " -24 " includes the last $24 \mathrm{~h}$ before calving, with calving taking place in the last 2 -h interval (interval -2 ) of that period. Data collected in periods -96 to -48 showed no difference in an exploratory analysis and were averaged to obtain a 24-h baseline value per cow. Data were analyzed using mixed models (PROC MIXED; SAS version 9.2; SAS Institute Inc., Cary, NC), with period as a repeated measure. Dunnett's 2-tailed test was used as a post hoc test to evalu- ate differences between baseline and subsequent 24-h periods. Residuals were examined to verify normality and homogeneity of variances and to detect possible outliers and influential points. $P$-values were considered significant at $<0.05$ and tendencies at $<0.10$. The 2 -h intervals from -48 to $22 \mathrm{~h}$ relative to calving were averaged across cows, and diurnal patterns were plotted for descriptive purposes.

Time spent ruminating decreased by $63.3 \pm 30.6 \mathrm{~min}$ in the $24 \mathrm{~h}$ before calving $(P=0.04)$ and by $132.8 \pm$ $35.3 \mathrm{~min}$ in the 24 -h period following expulsion of the calf $(P<0.001)$ compared with baseline $(426.1 \pm 26.5$ $\min / 24 \mathrm{~h}$; Figure 1). Time spent ruminating returned to baseline 24 to $48 \mathrm{~h}$ after calving $(428.9 \pm 26.5, P=$ $0.9)$.

Dry matter intake tended to decrease (by $3.8 \pm 1.9$ $\mathrm{kg})$ in the 24 -h period before calving $(P=0.06)$, but did not differ between baseline $(15.7 \pm 1.5 \mathrm{~kg}$ of DM/24 h) and $24 \mathrm{~h}$ after calving $(17.3 \pm 1.5 \mathrm{~kg}$ of DM/24 h; $P=$ $0.4)$. Time spent feeding decreased by $66.2 \pm 15.7 \mathrm{~min}$ in the $24 \mathrm{~h}$ before calving $(P<0.001)$ compared with baseline $(205.1 \pm 13.2 \mathrm{~min} / 24 \mathrm{~h})$. Time spent feeding remained suppressed in the $2 \mathrm{~d}$ after calving (by $82.1 \pm$ $17.9 \mathrm{~min}$ in the $24 \mathrm{~h}$ after calving and by $74.6 \pm 18.5$ min in the period from 24 to $48 \mathrm{~h}$ after calving; $P<$ 0.001 in both cases).

The diurnal pattern of rumination time (Figure 2) showed a decline in the $4 \mathrm{~h}$ before parturition and an increase in the $4 \mathrm{~h}$ following parturition. Dry matter intake and time spent feeding declined in the $8 \mathrm{~h}$ before parturition and increased over the $6 \mathrm{~h}$ following calving.

This study is the first to describe patterns of rumination and feeding behavior around parturition, taking into consideration the time when the calf was expelled.

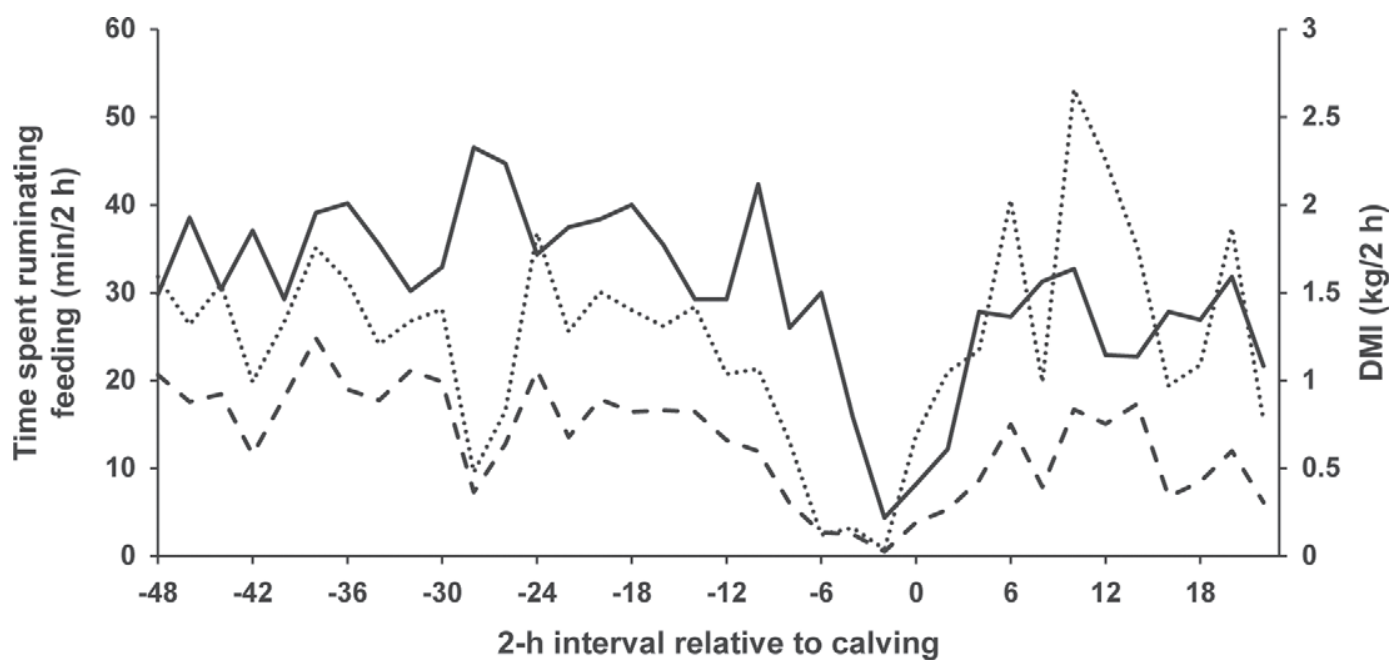

Figure 2. Changes in time spent ruminating (solid line), DMI (dotted line), and time spent feeding (dashed line) in 2-h intervals from $48 \mathrm{~h}$ before $(-48)$ to $24 \mathrm{~h}$ after calving $(\mathrm{n}=11$ cows $)$. 
Cows decreased time spent ruminating by $15 \%$ in the $24 \mathrm{~h}$ before calving, and by $31 \%$ in the $24 \mathrm{~h}$ after calving compared with 2 to $4 \mathrm{~d}$ before calving. Adin et al. (2009) and Soriani et al. (2012) reported numerical decreases in rumination on the day of calving (defined as a set 24-h period for every day and every animal; e.g., from midnight to midnight) followed by a progressive increase in the following days, but did not correct for the time of calving (i.e., the calf could be expelled at any point during the course of the day of calving), potentially contributing to variability in the analyses. The decrease in rumination behavior in our study began about $4 \mathrm{~h}$ before expulsion of the calf, suggesting that caution is required in the use of daily rumination summaries for the purpose of identifying cows that are about to calve. Moving cows to the maternity pen could have contributed to this decrease in rumination. However, given that most of the cows were moved after the decrease commenced and that some cows were not moved until they calved, calving was likely a major factor contributing to the decrease in rumination.

Following parturition, rumination time increased but did not return to baseline values until $48 \mathrm{~h}$ after calving. Rumination is affected by stress (Bristow and Holmes, 2007) and altered by management changes such as regrouping (Schirmann et al., 2011). In the present study, cows were regrouped into a fresh-cow pen immediately after calving, milked twice a day, and fed a different (lactating) diet. Previous research has shown that a change in diet, especially in NDF (Yang and Beauchemin, 2006; Adin et al., 2009) or forage particle size (Krause et al., 2002), can affect time spent ruminating. Future work should better control for factors such as change in diet and regrouping, to assess the changes in rumination behavior after calving.

The decrease in rumination time was accompanied by decreased DMI and feeding time. As already described for rumination, the moving of animals may have also contributed to the decrease in feeding activity. We observed a tendency for DMI to decrease in the $24 \mathrm{~h}$ before calving by $24 \%$ compared with 2 to 4 d before calving; this decrease was primarily observed within 8 h of calving. Similarly, Proudfoot et al. (2009) found that DMI decreased $32 \%$ in the $24 \mathrm{~h}$ before calving compared with 2 d before calving. Bertics et al. (1992) reported a DMI decrease of $28 \%$ in the week precalving compared with a baseline recorded at $3 \mathrm{wk}$ before calving. Weber et al. (2013) also found a decrease in DMI as calving approached, but DMI was not adjusted for time of calving in their study.

Feeding time decreased by $32 \%$ in the $24 \mathrm{~h}$ before and by $40 \%$ in the $24 \mathrm{~h}$ after parturition compared with 2 to $4 \mathrm{~d}$ before calving. These results are also in agreement with Proudfoot et al. (2009), who described decreases of approximately 36 and 50\%, respectively, in the 24 $\mathrm{h}$ before and after calving, compared with $2 \mathrm{~d}$ before calving. Miedema et al. (2011) monitored time spent feeding (summarized in 6-h periods) during the day of calving and found a decrease in the $6 \mathrm{~h}$ before calving compared with the same time periods on the day before calving. That result corresponds with the findings from the current study showing a decrease in feeding time starting approximately $8 \mathrm{~h}$ before calf expulsion. Changes in diet in the current study likely contributed to shorter feeding times after calving because diets with lower forage and higher energy contents are consumed faster than bulkier diets (Krause et al., 2002).

In conclusion, time spent ruminating and feeding, and to a lesser degree DMI, decreased in the hours around calving. Frequent measures of feeding and rumination show promise as tools to identify cows as they approach labor, but the use of 24-h summaries to predict calving should be viewed with caution.

\section{ACKNOWLEDGMENTS}

We are grateful to the students and staff of the University of British Columbia's Animal Welfare Program (Vancouver, BC, Canada) and Dairy Education and Research Centre (Agassiz, BC, Canada). Wolfgang Heuwieser (Clinic for Animal Reproduction of Freie Universität Berlin, Germany) is warmly thanked for providing us the HR-Tag rumination monitoring system. The Animal Welfare Program is funded by Canada's Natural Sciences and Engineering Research Council (Ottawa, ON, Canada) Industrial Research Chair Program with industry contributions from the Dairy Farmers of Canada (Ottawa, ON, Canada), Westgen Endowment Fund (Milner, BC, Canada), Pfizer Animal Health (Kirkland, QC, Canada), BC Cattle Industry Development Fund (Kamloops, BC, Canada), the BC Milk Producers (Burnaby, BC, Canada), BC Dairy Foundation (Burnaby, BC, Canada), BC Dairy Industry Research and Education Fund (Abbotsford, BC, Canada), and Alberta Milk (Edmonton, AB, Canada).

\section{REFERENCES}

Adin, G., R. Solomon, M. Nikbachat, A. Zenou, E. Yosef, A. Brosh, A. Shabtay, S. J. Mabjeesh, I. Halachmi, and J. Miron. 2009. Effect of feeding cows in early lactation with diets differing in roughageneutral detergent fiber content on intake behavior, rumination, and milk production. J. Dairy Sci. 92:3364-3373.

AOAC International. 2005. Official Methods of Analysis. 18th rev. ed. AOAC International, Arlington, VA.

Berglund, B., J. Philipsson, and O. Danell. 1987. External signs of preparation for calving and course of parturition in Swedish dairy cattle breeds. Anim. Reprod. Sci. 15:61-79.

Bertics, S. J., R. C. Grummer, C. Cardorniga-Valino, and E. E. Stoddard. 1992. Effect of prepartum dry matter intake on liver triglyceride concentration and early lactation. J. Dairy Sci. 75:19141922. 
Bristow, D. J., and D. S. Holmes. 2007. Cortisol levels and anxietyrelated behaviors in cattle. Physiol. Behav. 90:626-628.

Canadian Council on Animal Care (CCAC). 2009. CCAC guidelines on: The care and use of farm animals in research, teaching and testing. CCAC, Ottawa, Ontario, Canada.

Carrier, J., S. Godden, J. Fetrow, S. Stewart, and P. Rapnicki. 2006. Predictors of stillbirth for cows moved to calving pens when calving is imminent. Page 158-159 in Proc. 39th Ann. Am. Assoc. Bovine Pract., Auburn, AL.

Chapinal, N., D. M. Veira, D. M. Weary, and M. A. G. von Keyserlingk. 2007. Technical note: Validation of a system for monitoring individual feeding and drinking behavior and intake in grouphoused dairy cattle. J. Dairy Sci. 90:5732-5736.

Cumberland Valley Analytical Services. 2013. Resources: Lab procedures Accessed Mar. 14, 2013. http://www.foragelab.com/ Resources/Lab-Procedures/.

Kilgour, R. J. 2012. In pursuit of "normal": A review of the behavior of cattle at pasture. Appl. Anim. Behav. Sci. 138:1-11.

Kononoff, P. J., A. J. Heinrichs, and D. R. Buckmaster. 2003. Modification of the Penn State forage and total mixed ration particle separator and the effects of moisture content on its measurements. J. Dairy Sci. 86:1858-1863.

Krause, K. M., D. K. Combs, and K. A. Beauchemin. 2002. Effects of forage particle size and grain fermentability in midlactation cows. II. Ruminal pH and chewing activity. J. Dairy Sci. 85:1947-1957.

Mainau, E., and X. Manteca. 2011. Pain and discomfort caused by parturition in cows and sows. Appl. Anim. Behav. Sci. 135:241-251.

Mee, J. F. 2004. Managing the dairy cow at calving time. Vet. Clin. North Am. Food Anim. Pract. 20:521-546.

Miedema, H. M., M. S. Cockram, C. M. Dwyer, and A. I. Macrae. 2011. Changes in the behavior of dairy cows during the $24 \mathrm{~h}$ before normal calving compared with behavior during late pregnancy Appl. Anim. Behav. Sci. 132:8-14.

Noakes, D. E., T. J. Parkinson, G. C. W. England, and G. H. Arthur. 2001. Parturition and the care of parturient animals. Pages 155-187 in Arthur's Veterinary Reproduction and Obstetrics. 8th ed. Saunders, Philadelphia, PA.

NRC. 2001. Nutrient Requirements of Dairy Cattle. 7th rev. ed. National Academy Press, Washington, DC.
Proudfoot, K. L., M. Bak-Jensen, P. M. H. Heegaard, and M. A. G. von Keyserlingk. 2013. Effect of moving dairy cows at different stages of labor on behavior during parturition. J. Dairy Sci. 96:1638-1646.

Proudfoot, K. L., J. M. Huzzey, and M. A. G. von Keyserlingk. 2009. The effect of dystocia on the dry matter intake and behavior of Holstein cows. J. Dairy Sci. 92:4937-4944.

Radostits, O. M., C. C. Gay, K. W. Hinchcliff, and P. D. Constable. 2007. Veterinary Medicine: A Textbook of the Diseases of Cattle, Horses, Sheep, Pigs and Goats. 10th ed. Elsevier Publishing, New York, NY.

Schirmann, K., N. Chapinal, D. M. Weary, W. Heuwieser, and M. A. G. von Keyserlingk. 2011. Short-term effects of regrouping on behavior of prepartum dairy cows. J. Dairy Sci. 94:2312-2319.

Schirmann, K., M. A. G. von Keyserlingk, D. M. Weary, D. M. Veira, and W. Heuwieser. 2009. Technical note: Validation of a system for monitoring rumination in dairy cows. J. Dairy Sci. 92:6052-6055.

Soriani, N., E. Trevisi, and L. Calamari. 2012. Relationships between rumination time, metabolic conditions and health status in dairy cows during the transition period. J. Anim. Sci. 90:4544-4554. http://dx.doi.org/10.2527/jas.2011-5064.

Vickers, L. A., D. M. Weary, D. M. Veira, and M. A. G. von Keyserlingk. 2013. Feeding a higher forage diet prepartum decreases incidences of subclinical ketosis in transition dairy cows. J. Anim. Sci. 91:886-894.

Weber, C., C. Hameter, A. Tuscherer, B. Losand, E. Kanitz, W. Otten, S. P. Singh, R. M. Bruckmaier, F. Becker, W. Kanitz, and H. M. Hammon. 2013. Variation in fat mobilization during early lactation differently affects feed intake, body condition, and lipid and glucose metabolism in high-yielding dairy cows. J. Dairy Sci. 96:165-180

Wehrend, A., E. Hofmann, K. Failing, and H. Bostedt. 2006. Behaviour during the first stage of labor in cattle: Influence of parity and dystocia. Appl. Anim. Behav. Sci. 100:164-170.

Yang, W. Z., and K. A. Beauchemin. 2006. Physically effective fiber: Method of determination and effects on chewing, ruminal acidosis, and digestion by dairy cows. J. Dairy Sci. 89:2618-2633. 